\title{
Aligning the Freshwater Health Index Indicator System against the Transboundary Water Governance Framework of Southeast Asia's Sesan, Srepok, and Sekong River Basin
}

\author{
Xiaofeng Liu ${ }^{1}{ }^{\mathbb{D}}$, Nicholas J. Souter ${ }^{2, *} \mathbb{D}$, Raymond Yu Wang ${ }^{3}$ and Derek Vollmer ${ }^{4}$ \\ 1 Department of Geography, The University of Hong Kong, Hong Kong 999077, China; \\ xiaofeng_liu@outlook.com \\ 2 Conservation International, Greater Mekong Program, Adelaide, SA 5005, Australia \\ 3 Center for Social Sciences, Southern University of Science and Technology, Shenzhen 518055, China; \\ wangyuray@connect.hku.hk \\ 4 Conservation International, Betty and Gordon Moore Center for Science, Arlington, VA 22202, USA; \\ dvollmer@conservation.org \\ * Correspondence: nsouter@conservation.org; Tel.: +61-489-925-994
}

Received: 10 September 2019; Accepted: 31 October 2019; Published: 4 November 2019

\begin{abstract}
Indicator systems can improve water governance by integrating and simplifying data on water resources. However, to our knowledge, no indicator systems have been comprehensively assessed against the water governance framework within which they operate. We assess the policy relevance of the Freshwater Health Index (FHI) to the governance frameworks of Lao PDR, Cambodia, and Viet Nam. These governance frameworks were chosen because the FHI has been applied to the transboundary Sesan, Srepok, and Sekong (3S) river basin, which traverses the three nations. We conduct an institutional analysis, assessing the FHI indicators against each nation's relevant laws, plans, policies and strategies, as well as international agreements. The FHI indicators varied in their alignment with the 3S's transboundary water governance framework. Ecosystem Vitality indicators, which measure environmental health, tended to show a greater alignment than Ecosystem Service indicators. The Governance and Stakeholders indicators, which assess aspects of the governance system, were highly relevant. Comparing the 3S FHI assessment results to the water governance framework provided a case for delivering environmental flows and headwater reforestation, and improving biodiversity protection and fish passage. The generally close alignment of FHI metrics with the $3 S^{\prime}$ s water governance frameworks shows that the FHI is a policy-relevant tool.
\end{abstract}

Keywords: Freshwater Health Index; legislation; transboundary water governance; integrated water resources management; Mekong; $3 \mathrm{~S}$ basin

\section{Introduction}

Numerous composite indices have been developed to assist water resource management and they vary in their purpose, method, and application [1]. Water resource condition indices have been developed to benchmark and monitor the status of freshwater systems, facilitate Integrated Water Resources Management (IWRM), prioritise investment, and raise public awareness [1]. Potential index users include community groups, local governments and municipalities, resource managers, national policy makers, international organisations, and the private sector. It is thought that, by simplifying complex systems and information, indices appeal to policy makers and water managers, who can use them to assist planning and monitoring [2-4]. However, simplification alone may not guarantee 
the adoption of an index as a management tool. An index's appeal can be increased by involving decision makers in selecting indicators that suit their information needs or administrative mandate $[1,5]$. An index's relevance to the governance system can also be increased by balancing salience, legitimacy, and credibility $[1,6]$. To be specific, providing useful information to water resource managers achieves salience; an unbiased index that respects divergent values provides legitimacy; and a scientifically robust index is credible [1]. Closely linking an index to the governance framework decision makers work in increases salience and provides legitimacy, thereby increasing relevance.

Water resource management operates within a governance framework, which comprises international conventions and agreements; national and provincial laws, policies, guidelines and plans; and informal traditional arrangements. Indices may fit within a water governance framework in a variety of ways. Bespoke indices are designed to address a specific law, plan or policy. For example, Australia's National Framework for the Assessment of River and Wetland Health was developed to meet the requirements of the Commonwealth National Water Commission Act 2004 [7], whilst the EU Water Framework Directive 2000/60/EC has driven the development of biomonitoring techniques that can be used to report against its objectives [8,9]. Made-to-measure indices can be modified to fit specific requirements. For example, in testing their enhanced Water Poverty Index, Pérez-Foguet and Garriga [2] adapted their Institutional Capacity indicator to fit Peru's legal framework. As local water committees are the responsible entities under the National Housing and Water Plan 2006-2015, they measured the percent of water supplies managed by such committees. Similarly, the Water Vulnerability Index [10] prescribes a range of components that measure water vulnerability, but leaves the selection of indicators open to data availability and expert opinion. Although not expressed by Sullivan [10], expert opinion can address relevance to the governance framework. Off-the-rack indices are pre-calculated, often using global datasets, and provide users with predetermined output. Examples include the on-line Aqueduct Water Risk Atlas [11] and the Global Water Tool [12], which provide globally comprehensive and spatially explicit information for a range of indicators that facilitate global or regional risk assessments.

Among these three categories of water indices, bespoke indices are the most policy-relevant, but, because of their specificity, they are unlikely to be widely transferrable. We know of no examples where the relevance of a made-to-measure or off-the-rack index has been assessed against a governance framework, despite the importance of demonstrating their relevance, utility, and, thus, potential for wider adoption. When links are made, they are often limited to a small subset of indicators (e.g., the enhanced Water Poverty Index, as described above). In this paper we assess the made-to-measure Freshwater Health Index (FHI) against the governance framework of Southeast Asia's transboundary Sesan, Srepok, and Sekong (3S) river basin in the Lower Mekong. We review the administrative and legal systems in the 3S's three riparian countries (Lao PDR, Viet Nam, and Cambodia). We then analyse how the individual FHI indicators align to relevant laws, plans, and policies and, using the recent $3 S$ case study [13], analyse the FHI's suitability in assessing compliance to these laws, plans, and policies.

\section{Research Area and Method}

\subsection{Research Area}

One of the three rivers that comprise the $78,650 \mathrm{~km}^{2} 3 S$ river basin, the Sekong originates in Lao PDR, while the Sesan and Srepok rise in Viet Nam (Figure 1). All three rivers flow into Cambodia, before merging shortly before their junction with the Mekong River. Accounting for only $10 \%$ of the total area of the Mekong Basin, the 3S contributes almost a quarter of the Mekong's annual discharge [14] and $15 \%$ of its suspended sediment [15]. Rich in biodiversity, the 3S supports 329 fish species [16], and is the Mekong's most important tributary system for preserving migratory fish [17]. Of the 3.4 million people who live in the 3S, almost one quarter live in poverty and rely on natural resources for their daily survival. The $3 \mathrm{~S}$ is highly vulnerable to climate change and it is predicted that some areas of the 
Srepok catchment may warm by $4{ }^{\circ} \mathrm{C}$ [18]. There are currently 66 operational dams in the $3 S$, eight more under contract or construction, and sites for another 37 have been identified [13]. Extensive dam construction in the $3 S$ could increase dry season flows by $63 \%$, whilst reducing wet season flows by $22 \%$ [19]. Dams could trap 80\%-97\% of the catchment's sediment [20]. Additionally, the Lower Sesan 2, Lower Srepok, and Sekong dam cascades are believed to have the most impact on fish migration and diversity [17].

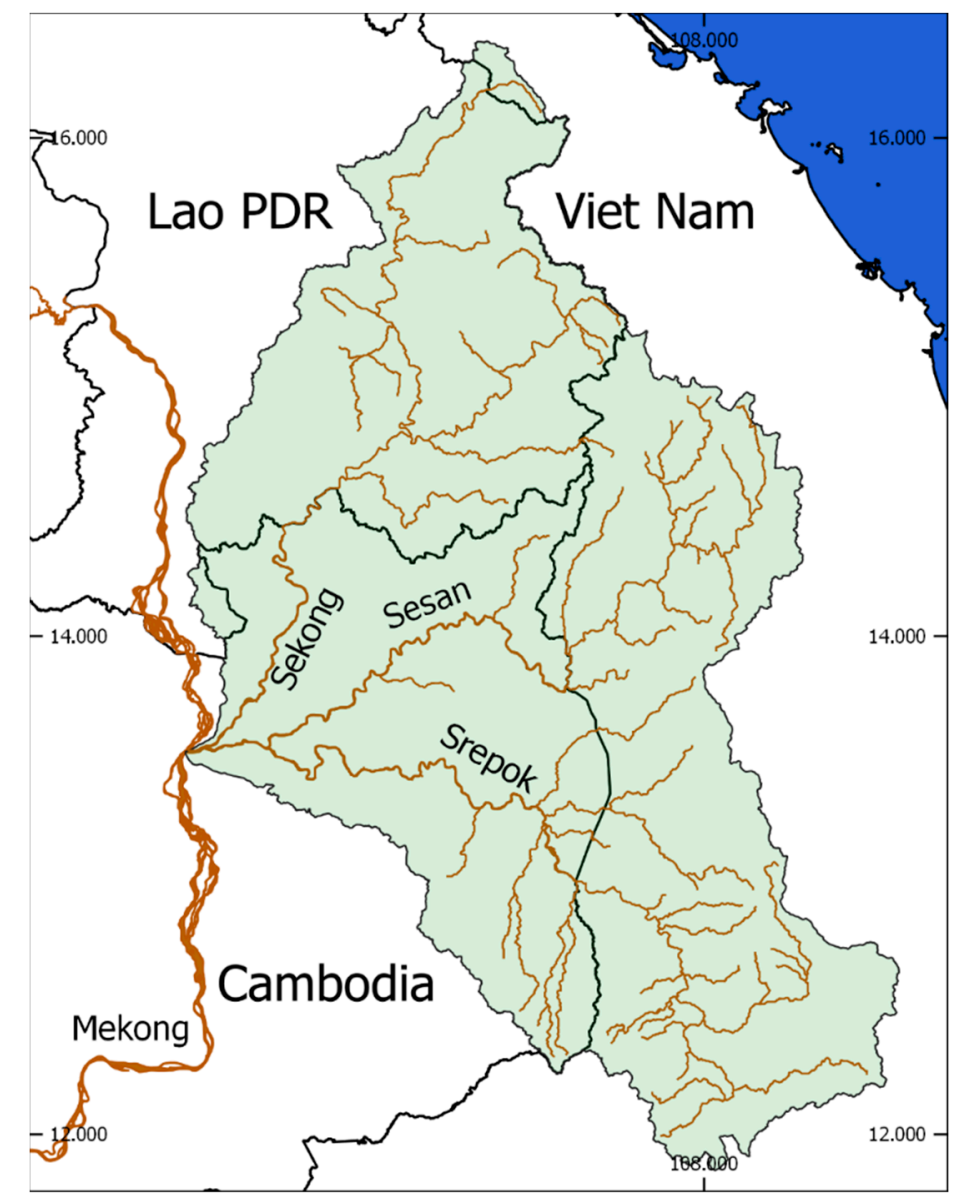

Figure 1. The Sekong, Sesan, and Sre Pok (3S) river basin (highlighted in green).

\subsection{Method}

The FHI quantitatively assesses freshwater ecosystem health in three dimensions: Ecosystem Vitality, Ecosystem Services, and Governance and Stakeholders [21]. Each of these dimensions is made up of a range of major and sub-indicators (Table 1), each of which is scored between 0 and 100. Ecosystem Vitality measures how much water-related biotic and abiotic parameters have changed from natural conditions. Ecosystem Services measures the benefits ecosystems provide to people. Governance and Stakeholders assesses formal institutions and regulations, informal social networks and beneficiary groups' involvement in water resource management, and the effectiveness of management institutions and practices [21]. Like the Water Vulnerability Index [10], the FHI gives the user the freedom to choose the most appropriate methods and data inputs for calculating full and sub-indicators. 
Table 1. Freshwater Health Indicator components, major indicators and sub-indicators, their $3 S$ basin score [13], and the number of laws, policies, and plans they align with, in each of the three countries.

\begin{tabular}{|c|c|c|c|c|c|}
\hline \multirow{2}{*}{ FHI Components, Major Indicators and Sub-Indicators } & \multirow{2}{*}{ FHI Score } & \multicolumn{4}{|c|}{ Number of Relevant Laws, Policies and Plans } \\
\hline & & International & Cambodia & Lao PDR & Viet Nam \\
\hline Ecosystem Vitality & 64 & & & & \\
\hline Water quantity & 66 & & & & \\
\hline Deviation from natural flow regime & 66 & 1 & 2 & 1 & 1 \\
\hline Groundwater storage & - & 0 & 1 & 1 & 1 \\
\hline Water quality & 81 & & & & \\
\hline Suspended solids, total Nitrogen, total Phosphorous, indicators of major concern & 81 & 2 & 3 & 1 & 2 \\
\hline Drainage-basin condition & 85 & & & & \\
\hline Extent of channel modification & 96 & 0 & 1 & 1 & 1 \\
\hline Flow connectivity & 78 & 0 & 0 & 0 & 0 \\
\hline Land cover naturalness & 82 & 1 & 1 & 1 & 1 \\
\hline Biodiversity & 38 & & & & \\
\hline Changes in number and population size of species of concern & 31 & 1 & 3 & 3 & 3 \\
\hline Changes in number and population size of invasive and nuisance species & 46 & 1 & 1 & 1 & 1 \\
\hline Ecosystem Services & 80 & & & & \\
\hline Provisioning & 94 & & & & \\
\hline Water supply reliability relative to demand & 95 & 0 & 1 & 2 & 2 \\
\hline Biomass for consumption & 94 & 0 & 1 & 2 & 1 \\
\hline Regulation and support & 66 & & & & \\
\hline Sediment regulation & 39 & 0 & 0 & 1 & 1 \\
\hline Flood regulation & 81 & 1 & 1 & 1 & 3 \\
\hline Deviation of water quality metrics from benchmarks & 88 & 1 & 2 & 2 & 3 \\
\hline Exposure to water-associated diseases & 67 & 1 & 1 & 1 & 2 \\
\hline Cultural/aesthetic & 83 & & & & \\
\hline Conservation/cultural heritage sites & 83 & 1 & 1 & 1 & 2 \\
\hline Recreation & - & & & & \\
\hline Governance and Stakeholders & 43 & & & & \\
\hline Enabling environment & 42 & & & & \\
\hline Water resource management & 50 & 5 & 3 & 2 & 3 \\
\hline Rights to resource use & 45 & 5 & 1 & 1 & 2 \\
\hline Incentives and regulations & 45 & 5 & 1 & 1 & 2 \\
\hline Financial capacity & 42 & 5 & 0 & 0 & 2 \\
\hline Technical capacity & 36 & 5 & 1 & 1 & 2 \\
\hline
\end{tabular}


Table 1. Cont.

\begin{tabular}{|c|c|c|c|c|c|}
\hline \multirow{2}{*}{ FHI Components, Major Indicators and Sub-Indicators } & \multirow{2}{*}{ FHI Score } & \multicolumn{4}{|c|}{ Number of Relevant Laws, Policies and Plans } \\
\hline & & International & Cambodia & Lao PDR & Viet Nam \\
\hline Stakeholder engagement & 46 & & & & \\
\hline Information access and knowledge & 41 & 6 & 3 & 2 & 2 \\
\hline Engagement in decision-making processes & 51 & 6 & 4 & 1 & 2 \\
\hline Vision and adaptive governance & 43 & & & & \\
\hline Strategic planning and adaptive governance & 39 & 4 & 3 & 1 & 2 \\
\hline Monitoring and learning mechanisms & 47 & 4 & 2 & 1 & 2 \\
\hline Effectiveness & 43 & & & & \\
\hline Enforcement and compliance & 37 & 1 & 0 & 0 & 0 \\
\hline Distribution of benefits from ecosystem services & 42 & 2 & 0 & 0 & 1 \\
\hline Water-related conflict & 45 & 2 & 1 & 2 & 1 \\
\hline
\end{tabular}

Note: FHI scores previously reported by Souter et al. [13]; relevant laws, policies and plans are the subject of the present research. 
The results of Souter et al. [13] December 2016 FHI assessment (A summary of these findings is also available from the FHI website, http://www.freshwaterhealthindex.org/basin-reports.) found that, whilst the $3 S$ basin's water ecosystem was showing signs of stress (with an Ecosystem Vitality score of 64), it provided a suite of desired ecosystem services (with an Ecosystem Services score of 80), but the water governance system was weak (with a Governance and Stakeholders score of 43). The work of Souter et al. [13] also assessed a range of future hydropower scenarios, which predicted that, as the number of dams increased, Ecosystem Vitality and Ecosystem Service scores will decline.

In order to inspect whether the FHI indicators are relevant to the water governance system in the 3S, we reviewed 82 water-related strategies, plans, laws, or decrees, of which 20 were enacted by international or regional agencies, 20 by Cambodia, 21 by Lao PDR, and 21 by Viet Nam. Then, this paper elaborates each indicator's connotation, and how it can address specific issues that are pointed out in laws, policies and plans.

\section{The $3 S^{\prime}$ Water Governance Framework}

\subsection{Global Agendas}

The United Nations (UN) has issued three conventions and protocols relevant to water governance in the 3S. The Convention on Biological Diversity (CBD) was ratified by each nation in 1996, and aims to protect aquatic biodiversity and ensure the sustainability of water delivery systems [22,23]. The Convention on the Law of Non-Navigational Uses of International Watercourses (UNWC), came into force in 2014, when Viet Nam became the 35th global signatory. The UNWC provides a solid foundation for the sustainable and peaceful management and conservation of international watercourses [24-27]. Neither Cambodia nor Lao PDR have signed the convention. The Sustainable Development Goals (SDGs) were established in 2015 and have been adopted by the three nations, within which SDG Six aims to ensure the availability and sustainable management of water, and sanitation for all [27,28]. Water-related ecosystem vitality, an FHI component, is highlighted by SDG Target 6.6.

Other international agencies, including the World Bank, the World Commission of Dams (WCD), and International Hydropower Association (IHA), have safeguard policies that require environmental and social assessments for infrastructure projects, especially hydropower, which the FHI addresses through future scenarios.

\subsection{Regional Agencies and Cooperation Mechanisms}

Lower Mekong Basin countries cooperate through a range of bilateral and multilateral mechanisms. The Mekong River Commission (MRC) is the primary water management organization, but other bodies and initiatives include the Association of Southeast Asia Nations (ASEAN), Greater Mekong Subregion, Asian Development Bank (ADB), Asia Pacific Economic Cooperation, Asia-Europe Meeting, Lower Mekong Initiative, Lancang-Mekong Cooperation, and Mekong-Japan Cooperation. Since the Agreement on the Cooperation for the Sustainable Development of the Mekong (Mekong Agreement) was signed in 1995, the MRC has published detailed guidelines, procedures and strategies concerning hydropower, water quality, and water use monitoring. In addition, the ASEAN Strategic Plan of Action on Water Resources Management and the ADB's Water for All Policy and Vision 2001 and Water Operational Plan 2011-2020 also set strategies and visions for their member countries, including Cambodia, Lao PDR, and Viet Nam.

The focus of international governance on the Mekong generally concerns the river's main stem [29]. Like all tributaries, the $3 \mathrm{~S}^{\prime}$ rivers are not covered under the Mekong Agreement. But, under the MRC's Mekong Integrated Water Resources Management project, a range of projects have been undertaken in the 3S, including the Sesan and Srepok River Basins Water Resources Management Project [30]. Additional studies include the ADB's Sesan, Srepok, and Sekong River Basins Development Study, the Mekong Water Resources Assistance Strategy supported by the World Bank, ADB, and MRC, and the IUCN's Building River Dialogues and Governance Programme (www.3sbasin.org). The International 
Rivers Network has also contributed to developing transboundary water governance in the $3 \mathrm{~S}$ basin. These regional programs and agreements mainly concentrate on water governance, capacity building and strategic planning, with some addressing aspects of Ecosystem Vitality, such as water quality and biodiversity, as well as the Ecosystem Service of flood control.

\subsection{Basin, National and Provincial Governance}

Transboundary provincial cooperation has been established in the 3S. The Cambodia-Viet Nam Bilateral Water Cooperation for the cross-border management of the Sesan-Srepok River was facilitated by the Mekong IWRM Project [31], which aims to strengthen provincial dialogue and improve local responses to transboundary water management issues. However, this process must overcome each nation's lack of subnational policies that could promote flexibility in governing the $3 S$ basin [32].

In Cambodia, the Ministry of Water Resources and Meteorology, and, in Lao PDR, the Ministry of Natural Resources and Environment are the lead agencies responsible for water resource management. In Viet Nam, the National Water Resources Council holds an advisory position regarding water resource management, whilst the Ministry of Natural Resources and Environment is responsible for its implementation. In each country, other ministries and authorities are responsible for related components of water management (Table S1).

Viet Nam's Law on Water Resources 2012 (Viet Nam's water law), Cambodia's Law on Water Resource Management 2007 (Cambodia's water law) and Lao PDR's Law on Water Resources 2013 (Lao PDR's water law) provide the foundation for national water governance in each nation. Water-related regulations and sub-decrees have been issued or amended to address rapid development and growing international integration [33] in regulating water use rights, licensing mechanisms, and flood control. Clauses and articles addressing pollution prevention, water quality, water supply, water use and allocation, irrigation, flood control, and climate change, are common to the three countries' water laws. Provisions for capacity building and stakeholder participation are also present, and address the need to improve technology and engage non-state actors and communities. Transboundary issues are more elaborated in Lao PDR and Viet Nam's water laws than Cambodia's. In addition to each nations' water law, a range of legislation and policies concerning water supply, forests, fisheries, environment, biodiversity, and energy also address river health and conservation (Table S2).

On provincial level, the $3 S$ transverses multiple provinces in the three countries-Stung Treng, Ratanakiri, and Mondulkiri in Cambodia; Sekong, Attapeu, Champasak, and Saravan in Lao PDR; and Kon Tum, Gia Lai, Dak Lak, and Thua Thien-Hue in Viet Nam. A variety of institutions responsible for water management are present in these provinces at the subnational level. For reasons of brevity, and the international transboundary focus of our assessment, we do not discuss these arrangements in detail.

\section{Alignment of FHI Metrics against Water-Related Legislation in the $3 \mathrm{~S}$}

The FHI indicators showed a high degree of alignment with the water governance system in the 3S. A few indicators were relevant to multiple laws, policies, and plans in each country (e.g., water quality and biodiversity); most were relevant to only one or two laws, policies, or plans, in one or two countries (e.g., groundwater storage, biomass for consumption); some were indirectly addressed by related factors (e.g., sediment regulation); whilst others did not relate to existing formal management arrangements (e.g., flow connectivity) (Table 1).

\subsection{Ecosystem Vitality}

The FHI Ecosystem Vitality indicator comprises four major indicators: water quantity, water quality, drainage-basin condition, and biodiversity. Ecosystem protection is highlighted by several international strategies: SDG Target 6.6 aims to protect and restore water related ecosystems; ADB's Water for All policy 2001 fosters water conservation; and MRC's Basin Development Strategy 2016-2020 for the Lower Mekong Basin includes an environmental dimension within its Indicator Framework. On the 
national level, Lao PDR's water law stresses the protection of wetland ecosystems (Article 49) and reservoirs (Article 53). But Viet Nam and Cambodia's water laws do not include strategies for aquatic ecosystem protection. Aquatic ecosystem protection is included as a strategic goal in both Cambodia's National Biodiversity Strategy Action Plan 2002 and Lao PDR's National Biodiversity Strategy and Action Plan 2016-2025. However, such emphasis is lacking in Viet Nam. The full suite of FHI Ecosystem Vitality metrics directly assess these targets and help set priorities for improving river ecosystem protection. Thus, improving ecosystem function in the $3 \mathrm{~S}$ river basin, as suggested by the FHI score, is broadly justified under these laws and strategies, but may hold more relevance in Lao PDR and Cambodia than in Viet Nam.

\subsubsection{Water Quantity}

The FHI measures water quantity with two sub-indicators: deviation from the natural flow regime and groundwater storage depletion.

Deviation from natural flow regime measures the change in the surface water flow regime, when compared to natural, unregulated conditions. The Mekong Agreement 1995 has member states cooperating to ensure that mainstream flows are maintained (Article 6). Under Viet Nam's water law, water resources will be managed for water quantity (Article 3.2), which will be assessed by surveys (Article 12.2c) and included in master plans (Article 19.1a). Cambodia's water law requires a yearly water resource inventory, which includes a measure of water quantity (Article 8). Lao PDR's water law states that flow be provided to satisfy people's needs and preserve the ecological balance (Article 30). Similarly, Cambodia's National Biodiversity Strategy and Action Plan 2002 states that minimum stream flows and lake levels are required to protect the environment and fisheries (Theme 12 Water Resources, No.2 strategic objective). The deviation from natural flow regime sub-indicator can be used to report against relevant provisions under the Mekong Agreement 1995, and the legislation and policies of Cambodia and Lao PDR that address ecosystem needs. The Vietnamese legislation does not specifically associate water quantity with ecological needs, but, by stating that water resources be managed for quantity, could make use of the sub-indicator. None of the documents we reviewed provide specific details as to how to measure compliance, as neither minimum nor seasonal flows have been specified. The deviation from natural flow regime indicator can assist with this, and the score of 66 [13] for the 3S suggests that that the flow regime does not provide adequate flows to the Mekong River. The current flow regime also does not protect aquatic ecosystems, as the $3 S^{\prime}$ fish community has shifted from a specialist to generalist community [34]. Thus, restoring natural components of the flow regime of the $3 S$ rivers is legally justified.

Groundwater storage depletion measures a decline in groundwater level against natural conditions. Viet Nam's water law defines a permissible groundwater exploitation limit to assure no water source deterioration or depletion (Article 2.19). Water resource surveys need to assess groundwater depletion (Article 12.2e), and water sources need to be classified according to the degree and scope of pollution and depletion, and be listed in order of priority for preparing rehabilitation plans (Article 27.4a). Both Cambodia's water law (Articles 20 and 21) and Lao PDR's water law (Articles 40-43) require the protection and licensing of groundwater resources. Due to a lack of data, the groundwater storage depletion sub-indicator was not calculated as a part of the 3S FHI assessment, and we cannot assess this metric against the legislation. The indicator is directly relevant to the groundwater sections in three countries' water laws.

\subsubsection{Water Quality}

The Ecosystem Vitality water quality metric assesses four sub-indicators (Table 1) against thresholds for the protection of aquatic ecosystem health. The MRC's Procedures for Water Quality 2011 states a goal of maintaining acceptable water quality on the mainstream (5.1.1), and strengthening programmes for monitoring and assessing the water quality of the Mekong River (5.1.2). The MRC has developed water quality guidelines for the protection of aquatic ecosystems in the lower Mekong Basin [35]. Viet Nam's 
water law defines clean water against a series of regulations, and states that water resources will be managed to protect water quality (Articles 3.2 and 3.4), and specifies that water quality be included in surveys, master plans and water resource maps (Articles 12.2c, $d$ and 19.1a). Viet Nam's water law also provides for the protection of groundwater quality (Articles 2.19 and 12.2e). Under Cambodia's water law, yearly water resource inventories assess water quality (Article 8) and the development of new technologies that will improve water quality are encouraged (Article 35). Under Lao PDR's water law, river basin management plans must evaluate water quality (Article 15), and quality standards of natural waters and standards of wastewater discharge should be determined by the government or stakeholders (Article 31). Viet Nam has established quality guidelines for the protection of surface and ground water (Type A1 of QCVN 08-MT:2015/BTNMT for domestic water supply, aquatic animal and plant conservation). Cambodia's Sub-decree No 27 on the Control of Water Pollution 1999 includes water quality standards for biodiversity conservation in rivers (Table S3). However, Lao PDR does not, at present, have water quality standards for ecosystem protection. In assessing the $3 \mathrm{~S}$ basin, Souter et al. [13] used the lower Mekong protection of aquatic ecosystems water quality guidelines [35], as these were most appropriate for this transboundary basin. With modification of the thresholds to suit local guidelines, the water quality indicator can be aligned with national legislation and policies in Viet Nam and Cambodia.

\subsubsection{Drainage Basin Condition}

Drainage basin condition measures how the river channel and basin land cover have changed from their natural condition. The indicator comprises three sub-indicators:

Channel modification measures the extent of unmodified or natural river channel, which allows for the natural exchange of materials laterally between the stream and its banks. We could not find any relevant laws or policies that seek to limit the extent of river channel modification, except through protecting riverbanks from erosion. In Cambodia's water law, behaviours that cause land subsidence or erosion should be sanctioned (Article 36.2). Viet Nam's water law forbids exploitation that causes bank erosion or seriously affects rivers' stability and safety (Article 9.5). Lao PDR's water law requires research regarding river width and narrowness, and protection from soil erosion when establishing protected areas (Article 39). Indeed, hard engineering solutions, used to control erosion, will modify the riverbank and reduce the naturalness score. Thus, an unintended consequence of complying with this legislation could be a reduction in the channel naturalness score.

Flow connectivity measures the extent to which human-made physical barriers disrupt the ability of aquatic animals, and materials such as sediment, to move freely through the river system. Despite the importance of fisheries and sediment flow in the Lower Mekong, we did not find any laws or policies related to this sub-indicator.

Land cover naturalness measures the degree to which land cover has changed from its natural state. Each of the three countries' forest laws address water-related issues. Cambodia's Law on Forestry 2002 protects both forests that regulate water sources and watersheds (Article 10). Lao PDR's Forestry Law 2007 protects the forests from which rivers, streams and creeks originate and flow (Article 26). Viet Nam's Law on Forest Protection and Development 2004 protects headwater forests (Article 4.1a). Although no laws directly address wetland resources in the three countries, following the signing of the Ramsar Convention 1971, several Ramsar sites were established to protect wetlands in the 3S [36]. Thus, the land cover naturalness indicator aligns with the three forestry laws. Whilst Lao PDR's Forestry Strategy to the Year 2020 and Vietnam's Forestry Development Strategy for the Period of 2006-2020 have national forest cover targets of $70 \%$ and $47 \%$, respectively, neither they nor Cambodia have forest cover targets specific to the $3 \mathrm{~S}$ basin.

\subsubsection{Biodiversity}

The biodiversity indicator comprises two sub-indicators: changes in number and population size of species of concern; and changes in number and population size of invasive and nuisance species. 
Species of concern measures the proportion of threatened freshwater species, change in the number of species of concern, and population trends. As signatories of the Convention on Biological Diversity 1992, all three countries have a national biodiversity strategy and action plans, with goals to protect biodiversity and sustainably use biological resources (Table S4). Viet Nam's Law on Biodiversity 2008 prohibits hunting, fishing and exploiting wild species in strictly protected sections of conservation areas (Article 7). Their Decree on Criteria to Determine Species and the Regime of Managing Species under Lists of Endangered. Precious and Rare Species Prioritized Protection 2013 prioritises endangered, precious, and rare species for protection under the IUCN Red List guidelines. Lao PDR's Wildlife and Aquatic Law 2007 divides wildlife and aquatic life into three categories, including prohibition, management, and common. Their Fisheries Law 2009 assigns fish species to these categories. Lao PDR's National Biodiversity Strategy and Action Plan 2016-2025 aligns biodiversity protection with the IUCN Red list. Although there is no biodiversity law in Cambodia, Royal Decree on the Protection of Natural Areas 1994 prohibits hunting, trapping, or fishing in protected areas (Article 2). Cambodia's National Biodiversity Strategy and Action Plan 2002 uses information from the Convention on the International Trade of Endangered Species (CITES), IUCN Red List and BirdLife International to categorise species for protection. The species of concern sub-indicator closely aligns with national laws and policies and presents a legal justification for improving biodiversity protection in the $3 S$.

Invasive and nuisance species measures invasive and nuisance species richness, change in richness, and population trends. The UNWC forbids the introduction of new or alien species into an international watercourse which may be detrimental to the ecosystem (Article 22). Viet Nam's Law on Biodiversity 2008 prohibits rearing or planting invasive alien species in conservation areas (Article 7). Cambodia's National Biodiversity Strategy and Action Plan 2002 aims to reduce the impact of alien invasive species on indigenous animal species (Objective 2.2). Lao PDR's National Biodiversity Strategy and Action Plan 2016-2025 aims to improve regulations, and the capacity to protect plants and animals in priority areas from alien species invasion (Target 1.5.5). The invasive and nuisance species sub-indicator closely aligns with legislation and plans in the three countries. However, a legal case for controlling invasive species is only present in Cambodia, as legislation in Lao PDR and Viet Nam only prohibit their introduction.

\subsection{Ecosystem Services}

The Ecosystem Services metrics consist of three major and eight sub-indicators (Table 1). The major indicators comprise provisioning, regulating and support, and cultural and aesthetic services, indicating the capacity of the ecosystem to provide these services. We found no direct mention of freshwater-related ecosystem services in the legislation reviewed, but each sub-indicator has diversified relevance to the policies.

\subsubsection{Provisioning}

The provisioning indicator comprises two sub-indicators: water supply reliability relative to demand, and biomass for consumption.

Water supply reliability relative to demand measures the ability of a basin to meet the spatial and temporal demand for various uses of water. The three countries each have a variety of water use permit or licensing mechanisms (Table S5). Cambodia's water law details the conditions and procedures for the granting, transfer, cancellation, time limitation, extension, and suspension of water use licenses (Articles 13-18). Lao PDR's water law requires individuals, legal entities, and organisations to access water according to the register of water resource use permits (Article 13). Lao PDR's Presidential Ordinance on Royalty Rate of Natural Resources 2015 charges different rates of water use for hydropower projects, and various production and service activities, including mining and water supply. Viet Nam's water law establishes the registration and licensing of water resource exploitation and use (Article 44). This FHI sub-indicator reveals whether demand for water is exceeding sustainable supply and decision-makers can use the indicator to issue water use licenses or permits in a rational 
manner, review the effectiveness of the current system, and ensure that water resources do not become overallocated. Whilst the high $3 S$ indicator score (95) suggests that abundant water is available, the lack of formal licensing and water use monitoring - despite the requirements of the legislation-is cause for concern, as development and demand for water increases.

Biomass for consumption measures the harvest of natural products from freshwater ecosystems. We have focused on the fisheries law, as the fishery is the most important source of biomass harvested from the 3S. Each of the three countries' fishery laws addresses habitat quality, as well as fish biodiversity, abundance, and biomass. Theme 3-Freshwater Fisheries and Aquaculture of Cambodia's National Biodiversity Strategy and Action Plan 2002-aims to improve food security, increase income from fisheries, preserve fisheries environment and sustainably expand fish production. Lao PDR's National Biodiversity Strategy and Action Plan 2016-2025 promotes the establishment and monitoring of Fish Conservation Zones and watershed programmes that support fish breeding sites (sub-strategy Action 1.2.1). Lao PDR's Fisheries Law 2009 sets rules to preserve wildlife and aquatic life in sustainable abundance (Article 25). Viet Nam's Law on Fisheries 2017 mandates the protection of aquatic species, their living and reproductive environment, and migration patterns (Article 13.1). The biomass for consumption sub-indicator can be used to report against these articles. The recently completed Lower Sesan II dam, although it has a fish pass, at least partially blocks important fish migration, and thus reduces the biomass sub-indicator score. This means that Cambodia may not be meeting its obligations and this likely also compromises Viet Nam's Law on Fisheries 2017. As the is Sekong River is open to migratory species, it upholds Lao PDR's Law on Fisheries 2007.

\subsubsection{Regulating and Support}

The regulating and support indicator has four sub-indictors: sediment regulation, flood regulation, deviation of water quality metrics from benchmarks, and exposure to water-associated diseases.

Sediment regulation measures the capacity of ecosystems to moderate the flow of sediments from land to streams, and deposit it on floodplains or deltas. Too much or too little sediment may harm river health, affecting not only water quantity and quality, but also aquatic life and land condition. We found no mention of sediment regulation in any of the documents reviewed. However, the topic is closely related to erosion, which could lead to an increase in sediment. Lao PDR's National Strategy for the Rural Water Supply and Environmental Health Sector 2004 states that sedimentation and erosion are harmful (Article 39). Viet Nam's water law requires the identification of river sections where bank erosion has occurred or is likely to occur (Article 19.3a), to control soil erosion and increase soil water-retaining capacity (Article 29.1; Article 63.). The sediment regulation sub-indicator can measure an increase in sediment supply and inform these articles. However, these articles address increases in sedimentation, but not decreases, which are important in this naturally sediment-rich system, as agriculture in the Mekong delta and aquatic wildlife depend on sediment for the nutrients it carries.

Flood regulation measures the ability of the socio-ecological system to reduce flooding and flood damage by slowing peak flows or absorbing flood waters. Viet Nam's laws and regulations related to flooding are the most developed of the three nations. Its Law on Dikes 2006 provides anti-flood planning, and the Law on Natural Disaster Prevention and Control 2013 seeks to prevent natural disasters, through controlling certain activities. Cambodia's water law (Article 24) and Lao PDR's water law (Article 15.2) require River Basin Management Plans, to evaluate risks within flood control areas or river basins and determine prevention or mitigation measures. Furthermore, the MRC has adopted the EU Flood Directive 2007. The three nations' legislation focuses on improving social resilience and response to the damaging effects of water-related disasters. The flood-regulation sub-indicator is directly relevant to the three nations' water governance framework, and its high score of 88 shows that the legislation is being upheld.

Deviation of water quality metrics from benchmarks measures the ecosystem's ability to moderate concentrations of water quality parameters relative to a range of human use standards. A variety of water quality standards, related to protecting human activities, have been established 
across the region (Table S6). ASEAN's Strategic Plan of Action on Water Resources Management 2005 sets standards for potable water, recreation, commercial fisheries, and irrigation. Ensuring clean water is common to each of the three countries' water laws, and quality standards are listed in regulations or decrees. Viet Nam's water law states that water for domestic use (Articles 32.2a, 54.1b) and agricultural production be of a suitable quality (Article 54.1b). Water quality guidelines have been developed for ambient surface water (QCVN 08-MT:2015/BTNMT) and groundwater (QCVN 09-MT:2015/BTNMT). Cambodia's water law requires licenses to undertake activities that may affect water quality and endanger human, animal and plant health (Article 22). Cambodia's Sub-decree No 27 on the Control of Water Pollution 1999 includes water quality standards, to ensure the protection of public health. Lao PDR's water law requires that water provided to urban and rural areas be safe for human use. Standards are detailed in their Water Quality Targets No 953MoH/14/7/03, enacted in 2003. These standards are easily applied to the deviation of water quality metrics from benchmarks sub-indicator, which can inform both policy and planning in the three nations. The $3 \mathrm{~S}$ results (score of 81) suggest that the legislation is being upheld.

Exposure to water-associated diseases measures their prevalence within a catchment. Whilst water associated diseases were not detailed in any of the water-related legislation, plans, or policies we reviewed, they are addressed in a range of other strategies. ADB's Water Operational Plan 2011-2020 states that water-related diseases are the most common cause of death and illness among the poor. Cambodia's Climate Change Strategic Plan 2014-2023 charges the Ministry of Health with improving healthcare infrastructure, and the capacity of health personnel to cope with vector-borne and water-borne diseases (Strategic Objective 2(j)). Lao PDR's 8th Five Year National Socio-Economic Development Plan 2016-2020 calls for special attention to ensure that Malaria does not spread and pose further threats (3.4.5.6 MDG 6). Viet Nam's Ordinance on Prevention and Control of Floods and Storms and Implementation Provisions 1993 charges the Ministry of Health with preventing diseases and epidemics from breaking out in flooded areas (Article 11.13; 26.4). Viet Nam's National Rural Clean Water Supply and Sanitation Strategy 2000 includes the goal of improving rural population health, by reducing water and sanitation related diseases by improving the water supply (2.1.1). Whilst the FHI indicator, as calculated for the 3S, does not directly address these clauses, it could, if data became available, be calculated to directly address the legislation.

\subsubsection{Cultural and Aesthetic Services}

The cultural/aesthetic indicator comprises two sub-indicators: conservation/cultural heritage sites and recreation. We could find no mention of cultural services in the legislation reviewed. However, conserving the cultural values of protected areas is legislated in each of the three countries (Table S7). In Cambodia's Protected Areas Law 2008, the National Protected Area Strategic Management Plan must include the status of natural resources and ecosystems, as well as socio-cultural and recreational aspects of Protected Areas (Article 17). Lao PDR's Forestry Law 2007 defines Conservation Forests as protected sites with natural, historical, cultural or tourism value (Article 11), and states that surveys of the historical and socio-cultural values of Production Forest areas are required (Article 25.2). In Viet Nam's water law, the protection of natural landscape, historical-cultural relics, scenic places and other natural resources is an important principle (Article 3.3) which should be detailed in water resource water plans (Article 6.1b). Furthermore, water source protection corridors are established for biodiversity, cultural conservation, or natural ecosystem protection (Article 1.1d). Viet Nam's Law on Biodiversity 2008 requires consideration of the cultural and historical values of species when proposing protection lists (Article 38.3c). The cultural services indicator for the 35 did not reflect the details contained within these laws, due to a lack of data. However, were such data available (e.g., the location and significance of water-related cultural sites), the indicator could be designed to assess compliance with these laws. 


\subsection{Governance and Stakeholders}

The Governance and Stakeholders indicators assess the level of stakeholders' involvement, the human, financial and institutional capacity needed to effectively manage water resources, and the effectiveness of management. The Governance and Stakeholders indicators are calculated via a self-assessment survey, which asks general questions of decision makers, but does not assess progress towards specific management goals, or conformity to legislation. In the 3S, Governance and Stakeholders scored 43, which revealed a low level of capacity, stakeholder engagement, policy implementation, and compliance with legislation [37]. These results show that, although relevant water resource management institutions, laws, and regulations exist (Table 1), their effectiveness and implementation within the 3S was low. The $3 S$ is located far from provincial and national capitals, making coordination among the three countries difficult, which is further compounded by limited capacity at provincial and national levels. For example, the Water Resource Management sub-indicator scored 50, despite the existence of Cambodia's Sub-decree on River Basin Management 2015, Lao PDR's Decree on Establishment and Activities of River Basin Committee 2010, Viet Nam's Decree on River Basin Management 2008, through which management, planning, basic surveys, environment surveys and protections, resource allocation, and responsibilities are regulated on a basin level. This suggests that, although the governance framework exists, it is not being fully implemented. Although most of the Governance and Stakeholders indicators are relevant to aspects of the water governance framework-especially international strategies-the low self-assessment score suggests that the policy framework is only partially being implemented. This shows that additional resources are required to manage the 3S, at least on a national level, to fulfil each nation's legislative requirements.

\subsection{Future Scenarios}

Future challenges, like climate change and energy development, are detailed in several water-related strategies, plans, and laws. The work of Souter et al. [13] explored the consequences of hydropower dam development on a range of indicators and sub-indicators, with the aim of informing future basin development options.

\subsubsection{Energy Development and Dam Construction}

Hydropower is an important component of each nations' energy development plans. Viet Nam's Law on Hydraulic Work 2017 details dam investment and operation guidelines. Community consultation is required prior to the construction of dams with a capacity greater than 500 million $\mathrm{m}^{3}$, according to Article 2.1 of Decree No. 201/2013/ND-CP Detailing the Implementation of a Number of Articles of the Law on Water Resources. Cambodia's water law requires a license or permit before dams are constructed (Article 12), and other agencies and local authorities need to be consulted before a license is issued (Article 14). In Lao PDR's water law, hydropower production ranks second in priority for water resource use (Article 17) and is a high priority in national energy strategies. Nationally, the impact of hydropower development on river ecosystems or measures to mitigate negative impacts receive scant attention. However, the MRC's Development of Guidelines for Hydropower Environmental Impact Mitigation and Risk Management in the Lower Mekong Mainstream and Tributaries 2015 describes five major hydropower risks and impacts: (1) hydrology and downstream flow; (2) geomorphology and sediments; (3) water quality; (4) fisheries and aquatic ecology; and (5) biodiversity, natural resources, and ecosystem services. The $3 \mathrm{~S}$ dam development scenarios show a decline in biomass for consumption, drainage basin condition and sediment regulation, as more dams are constructed [13]. This information can assist in interpreting the MRC guidelines and determining whether other related plans, policies, and laws will be affected by hydropower. 


\subsubsection{Climate Change}

Climate change is increasingly being considered in water resource planning and management. The UN Framework Convention on Climate Change 1995 urges cooperation in adapting to climate change impacts, developing integrated plans for water resources, and protected areas affected by drought and floods (Article 4.1e). Nationally, the Cambodia Climate Change Strategic Plan 2014-2023 aims to promote climate resilience through improving food, water, and energy security (Strategic Objective 1). Strategy on Climate Change of Lao PDR 2010 requires the development of climate change scenarios for river basins which, when coupled with hydrological models, can simulate future river flows and assess the impacts of climate change on riverbank erosion and hydropower development, and be used to develop adaptation strategies (3.3.1(2)). Viet Nam's National Strategy on Climate Change 2011 addresses the impact of climate change on water security and water resource management. Primarily using hydrological models, the FHI can model the impact of climate change scenarios on a range of indicators and sub-indicators and inform relevant strategies, though, at present, these have not been elaborated for the $3 S$.

\section{Discussion}

The made-to-measure FHI is highly relevant to the legislative and policy frameworks of Viet Nam, Cambodia, and Lao PDR, as well as a variety of international agreements. The FHI indicators varied in their alignment with the 3S's governance framework. In general, the Ecosystem Vitality suite of indicators was more closely related to the water governance framework than the Ecosystem Services indicators (Table 1). Most of the Governance and Stakeholders indicators were relevant to the governance framework (Table 1), which was expected, as they measure aspects of the water governance system. Except for water quality, the legislation, plans, and policies we reviewed provided ambiguous guidance on what constitutes compliance with legislation, and how to measure this. The FHI indicators can help to fill this gap and provide managers with the information they need to work within the water governance framework.

The $3 \mathrm{~S}$ FHI assessment has provided legal justification for restoring components of the natural flow regime through providing environmental flows, potential reforestation in the headwaters of all three rivers, improving biodiversity protection, and improving fish passage past current and any future dams. The two water quality indicators, flood regulation and water supply relative to demand, were all compliant with the relevant laws, plans, and policies in the three countries.

Although not addressed in this paper, a separate study has aligned the FHI to components of Sustainable Development Goal (SDG) 6-ensure availability and sustainable management of water and sanitation for all-in Cambodia [37]. It revealed a similar pattern to this study, with a greater alignment with Ecosystem Vitality metrics than Ecosystem Services. A subset of Governance and Stakeholders indicators can be used to assess some of the SDGs.

One of the aims of the FHI is to provide a comprehensive assessment of river basin health. This study has shown that, in each country, a complicated institutional and legal regime is spread over various laws, decrees, ordinances, and strategies, which are the responsibility of different agencies. The three countries are at different stages of developing their national, provincial, and local water governance frameworks, and they have distinct national interests, which may cause conflict between nations [38]. Whilst the priority of, and emphasis on, water conservation in the three countries' legislation varies, the FHI has been shown to reconcile these differences, and provide clarity and certainty when addressing legal principles, as well as identify priority issues that may require the attention of policy makers and water resource managers.

Our review has also revealed several gaps in the water governance framework of the 3S. Laws, policies, and plans concerning wetlands, sediment, channel modification, connectivity, and exposure to water-associated diseases require further development. Wetland protection within the $3 \mathrm{~S}$ is hindered by the lack of a specific wetlands law in each of the three countries, and we recommend the drafting and adoption of relevant legislation. Detailed standards for monitoring and controlling in-channel 
sediment flows, channel condition, and riverine connectivity are also lacking. Although the majority of FHI metrics are covered under the governance framework, the implementation of the policy framework needs to be improved, as revealed by the results of the Governance and Stakeholders survey.

\section{Conclusions}

Our assessment of the Freshwater Health Index against the water governance framework of the Sesan, Srepok, and Sekong River basin, which comprises the laws, policies, and plans of Lao PDR, Cambodia, Viet Nam and international agreements, showed that the FHI provides a suite of policy-relevant indicators. Aligning with the water governance framework, the FHI scores from the recent assessment of the $3 S$ basin provide managers with an assessment of whether current conditions in the basin are complying with the legal framework. The high level of agreement between the FHI metrics, the legal frameworks of these three countries and the international agreements, is likely to be reflective of other jurisdictions, widening the applicability of the FHI.

Supplementary Materials: The following are available online http://www.mdpi.com/2073-4441/11/11/2307/s1, Table S1: Major water-related responsibilities and institutional arrangement, Table S2. Priorities in water-related strategies, Table S3. Water quality thresholds requirement for ecosystem protection, Table S4. Lists of protected aquatic species, Table S5. Water use licensing mechanisms, Table S6. Water quality parameter guidelines for human use, Table S7. Major types of protected areas.

Author Contributions: Conceptualization, analysis and writing contributed by N.J.S. and X.L.; resources contributed by R.Y.W. and D.V.

Funding: This work was funded by grants from the Victor and William Fung Foundation and was undertaken as a part of the development of Conservation International's Freshwater Health Index. It is also supported by the National Natural Science Foundation of China (No. 41801132) and the Ministry of Education of Humanities and Social Science (No. 17YJCZH183).

Acknowledgments: The first author acknowledges the support of the China Scholarship Council.

Conflicts of Interest: The authors declare no conflict of interest.

\section{References}

1. Vollmer, D.; Regan, H.M.; Andelman, S.J. Assessing the sustainability of freshwater systems: A critical review of composite indicators. Ambio 2016, 45, 765-780. [CrossRef] [PubMed]

2. Pérez-Foguet, A.; Garriga, R.G. Analyzing water poverty in basins. Water Resour. Manag. 2011, 25, 3595. [CrossRef]

3. El-Gafy, E.D. The water poverty index as an assistant tool for drawing strategies of the Egyptian water sector. Ain Shams Eng. J. 2015, 9, 173-186. [CrossRef]

4. Juwana, I.; Muttil, N.; Perera, B.J. Indicator-based water sustainability assessment-A review. Sci. Total Environ. 2012, 438, 357-371. [CrossRef] [PubMed]

5. Sala, S.; Ciuffo, B.; Nijkamp, P. A systemic framework for sustainability assessment. Ecol. Econ. 2015, 119, 314-325. [CrossRef]

6. Cash, D.W.; Clark, W.C.; Alcock, F.; Dickson, N.M.; Eckley, N.; Guston, D.H.; Jäger, J.; Mitchell, R.B. Knowledge Systems for Sustainable Development. Proc. Natl. Acad. Sci. USA 2003, 100, 8086-8091. [CrossRef]

7. Norris, R.H.; Dyer, F.; Hairsine, P.; Kennard, M.; Linke, S.; Merrin, L.; Read, A.; Robinson, W.; Ryan, C.; Wilkinson, S.; et al. Australian Water Resources 2005. A Baseline Assessment of Water Resources for the National Water Initiative. Level 2 Assessment River and Wetland Health Theme Assessment of River and Wetland Health: A Framework for Comparative Assessment of the Ecological Condition of Australian Rivers and Wetlands; National Water Commission: Canberra, Austrilia, 2007.

8. Birk, S.; Bonne, W.; Borja, A.; Brucet, S.; Courrat, A.; Poikane, S.; Solimini, A.; Van De Bund, W.; Zampoukas, N.; Hering, D. Three hundred ways to assess Europe's surface waters: An almost complete overview of biological methods to implement the Water Framework Directive. Ecol. Indic. 2012, 18, 31-41. [CrossRef] 
9. Wernersson, A.-S.; Carere, M.; Maggi, C.; Tusil, P.; Soldan, P.; James, A.; Sanchez, W.; Dulio, V.; Broeg, K.; Reifferscheid, G.; et al. The European technical report on aquatic effect-based monitoring tools under the water framework directive. Environ. Sci. Eur. 2015, 27, 7. [CrossRef]

10. Sullivan, C.A. Quantifying water vulnerability: A multi-dimensional approach. Stoch. Environ. Res. Risk Assess. 2011, 25, 627-640. [CrossRef]

11. Gassert, F.; Luck, M.; Landis, M.; Reig, P.; Shiao, T. Aqueduct Global Maps 2.1: Constructing Decision-Relevant Global Water Risk Indicators; World Resources Institute: Washington, DC, USA, 2014.

12. WBCSD (World Business Council for Sustainable Development). Global Water Tool. Available online: http://www.wbcsd.org/work-program/sector-projects/water/global-water-tool.aspx (accessed on 30 July 2018).

13. Souter, N.J.; Shaad, K.; Vollmer, D.; Regan, H.M.; Farrell, T.; Arnaiz, M.; Meynell, P.-J.; Cochrane, T.; Arias, M.E.; Piman, T.; et al. Using the Freshwater Health Index to asses hydropower development scenarios in the Sesan, Srepok and Sekong River basin. 2019. In review.

14. Adamson, P.T.; Rutherfurd, I.D.; Peel, M.C.; Conlan, I.A. The Hydrology of the Mekong River. In The Mekong: Biophysical Environment of an International River Basin; Campbell, I.C., Ed.; Elsevier: Amsterdam, The Netherlands, 2009; pp. 53-76.

15. Koehnken, L. IKMP Discharge and Sediment Monitoring Programme Review, Recommendations and Data Analysis, Parts 1 \& 2. Technical Advice on Water; Lao PDR: Vientiane, Laos, 2012.

16. Baran, E.; Saray, S.; Teoh, S.J.; Tran, T.C. Fish and fisheries in the Sesan, Sekong and Srepok River basins (Mekong watershed). In On Optimizing the Management of Cascades or System of Reservoirs at Catchment Level; ICEM: Hanoi, Vietnam, 2014.

17. Ziv, G.; Baran, E.; Nam, S.; Rodríguez-Iturbe, I.; Levin, S.A. Trading-off fish biodiversity, food security, and hydropower in the Mekong River Basin. Proc. Natl. Acad. Sci. USA 2012, 109, 5609. [CrossRef] [PubMed]

18. US Agency for International Development. Mekong ARCC Climate Change Impact and Adaptation Study for the Lower Mekong Basin: Main Report; ICEM: Bangkok, Thailand, 2013.

19. Piman, T.; Lennaerts, T.; Southalack, P. Assessment of hydrological changes in the lower Mekong Basin from Basin-Wide development scenarios. Hydrol. Process. 2013, 27, 2115-2125. [CrossRef]

20. Wild, T.B.; Loucks, D.P. Managing flow, sediment, and hydropower regimes in the Sre Pok, Se San, and Se Kong Rivers of the Mekong basin. Water Resour. Res. 2014, 50, 5141-5157. [CrossRef]

21. Vollmer, D.; Shaad, K.; Souter, N.J.; Farrell, T.; Dudgeon, D.; Sullivan, C.A.; Fauconnier, I.; Macdonald, G.M.; Mccartney, M.P.; Power, A.G. Integrating the social, hydrological and ecological dimensions of freshwater health: The freshwater health index. Sci. Total Environ. 2018, 627, 304-313. [CrossRef]

22. Gleick, P.H. Global Freshwater Resources: Soft-Path Solutions for the 21st Century. Science 2003, 302, 1524-1528. [CrossRef]

23. Vörösmarty, C.J.; Mcintyre, P.B.; Gessner, M.O.; Dudgeon, D.; Prusevich, A.; Green, P.; Glidden, S.; Bunn, S.E.; Sullivan, C.A.; Reidy Liermann, C. Global threats to human water security and river biodiversity. Nature 2010, 467, 555-561. [CrossRef]

24. International Union for Conservation of Nature. A Window of Opportunity for the Mekong Basin: The UN Watercourses Convention as a Basis for Cooperation (A Legal Analysis of How the UN Watercourses Convention Complements the Mekong Agreement); IUCN Asia Regional Office: Bangkok, Thailand, 2016.

25. Rieu-Clarke, A.; Moynihan, R.; Magsig, B.-O. UN Watercourses Convention User's Guide; IHP-HELP Centre for Water Law, Policy and Science (under the auspices of UNESCO): Dundee, UK, 2012.

26. Zhong, Y.; Tian, F.; Hu, H.; Grey, D.; Gilmont, M. Rivers and reciprocity: Perceptions and policy on international Watercourses. Water Policy 2016, 18, 803-825. [CrossRef]

27. United Nations. Sustainable Development Goals Report 2016; United Nations: New York, NY, USA, 2016.

28. Ortigara, A.; Kay, M.; Uhlenbrook, S. A review of the SDG 6 synthesis report 2018 from an education, training, and research perspective. Water 2018, 10, 1353. [CrossRef]

29. Hirsch, P.; Wyatt, A. Negotiating local livelihoods: scales of conflict in the Se San River Basin. Asia Pac. Viewp. 2004, 45, 51-68. [CrossRef]

30. Mekong River Commission. Transboundary Water Resources Management Issues in the Sesan and Srepok River Basins of Cambodia and Viet Nam; Mekong River Commission: Vientiane, Lao PDR, 2017. 
31. Mekong River Commission. Core Mechanisms of Bilateral Water Cooperation Agreed for Sesan-Srepok and Mekong Delta. Available online: http://www.mrcmekong.org/news-and-events/news/core-mechanismsof-bilateral-water-cooperation-agreed-for-sesan-srepok-and-mekong-delta/ (accessed on 2 February 2018).

32. UN-Water. Status Report on IWRM and Water Efficiency Plans for CSD 16; UN-Water: Geneva, Switzerland, 2008.

33. Nguyen, T.P.L. The Legal Framework of Vietnam's Water Sector: Update 2013; Braun, J.V., Denich, M., Gerke, S., Hornidge, A.-K., Schetter, C., Eds.; Center for Development Research, University of Bonn: Bonn, Germany, 2013.

34. Ngor, P.B.; Legendre, P.; Oberdorff, T.; Lek, S. Flow alterations by dams shaped fish assemblage dynamics in the complex Mekong-3S river system. Ecol. Indic. 2018, 88, 103-114. [CrossRef]

35. Ly, K.; Larsen, H. 2014 Lower Mekong Regional Water Quality Monitoring Report; Mekong River Comission: Vientiane, Laos, 2016.

36. Torell, M.; Salamanca, A.M.; Ratner, B.D. Wetlands Management in Cambodia: Socioeconomic, Ecological, and Policy Perspectives; WorldFish Center: Penang, Malaysia, 2004.

37. Souter, N.J.; Shaad, K.; Vollmer, D. Using the Freshwater Health Index to Assess Progress toward Sustainable Development Goal 6, Clean Water and Sanitation, in Cambodia. In Environmental Sustainability in Asia: Progress, Challenges and Opportunities in the Implementation of the Sustainable Development Goals, Series 2-Cambodia; Korea Environment Institute: Sejong, Korea, 2019; pp. 80-97.

38. Dore, J.; Lebel, L. Deliberation and Scale in Mekong Region Water Governance. Environ. Manag. 2010, 46, 60-80. [CrossRef] [PubMed]

(C) 2019 by the authors. Licensee MDPI, Basel, Switzerland. This article is an open access article distributed under the terms and conditions of the Creative Commons Attribution (CC BY) license (http://creativecommons.org/licenses/by/4.0/). 